\title{
Sculpture in the Sun
}

Hawaii’s Art for OpenSpaces 



\section{Sculpture in the Sun}

Hawaii’s Art for OpenSpaces

Georgia and Warren Radford

Photographs by Rick Golt 
Copyright () 1978 by

The University Press of Hawaii

All rights reserved. No part of this work may be reproduced or transmitted in any form or

by any means, electronic or mechanical, in-

cluding photocopying and recording, or by any

information storage or retrieval system, with-

out permission in writing from the publisher.

Manufactured in the United States of America

Library of Congress Catalog Card No.

77-92972

ISBN: 0-8248-0526-7 